\title{
ERRATUM
}

\section{Erratum to: Identification of gene variants associated with hypoxia pathway in acute coronary syndrome: a pilot study}

Cahide Gokkusu • Bedia Cakmakoglu •

Zeynep Birsu Cincin - Mehmet Kocaaga •

Samim Emet $\cdot$ Sule Tamer $\cdot$ Berrin Umman

Published online: 7 October 2014

(C) Springer Science+Business Media Dordrecht 2014

Erratum to: Mol Biol Rep

DOI 10.1007/s11033-014-3703-7

The fourth author's family name should be read as

'Kocaaga' instead of 'Karaagac'.

The online version of the original article can be found under doi:10.1007/s11033-014-3703-7.

C. Gokkusu ( $\square)$

Department of Biochemistry, Faculty of Medicine, Istanbul

University, Capa, Istanbul, Turkey

e-mail: cgokkusu@gmail.com

B. Cakmakoglu $\cdot$ Z. B. Cincin

Department of Molecular Medicine, Institute for Experimental

Medicine Research, Istanbul University, Istanbul, Turkey

M. Kocaaga $\cdot$ S. Emet $\cdot$ B. Umman

Department of Cardiology, Faculty of Medicine, Istanbul

University, Istanbul, Turkey

S. Tamer

Department of Physiology, Faculty of Medicine, Istanbul

University, Istanbul, Turkey 